\title{
The Helicobacter pylori CagF protein is a type IV secretion chaperone-like molecule that binds close to the C-terminal secretion signal of the CagA effector protein
}

\author{
Isabelle Pattis, Evelyn Weiss, Romy Laugks, Rainer Haas \\ and Wolfgang Fischer
}

\begin{abstract}
Correspondence
Wolfgang Fischer

fischer@mvp.uni-muenchen.de
\end{abstract}

Received 22 February 2007

Revised 31 May 2007

Accepted 4 June 2007

\author{
Max von Pettenkofer-Institut für Hygiene und Medizinische Mikrobiologie, Ludwig-Maximilians- \\ Universität, Pettenkoferstr. 9a, 80336 München, Germany
}

\begin{abstract}
Type IV secretion systems are common bacterial macromolecule transporters that have been adapted to various functions, such as effector protein translocation to eukaryotic cells, nucleoprotein transfer to bacterial or eukaryotic cells, and DNA transport into and out of bacterial cells. Helicobacter pylori, the causative agent of bacterial gastritis, peptic ulcers, gastric adenocarcinoma and mucosa-associated lymphoid tissue (MALT) lymphoma, uses the Cag type IV secretion system to inject the CagA protein into host cells, thereby altering gene expression profiles and the host cell cytoskeleton. The molecular mechanism of CagA recognition as a type IV substrate is only poorly understood, but seems to be more complex than that of other type IV secretion systems. Apart from 14 essential components of the secretion apparatus, CagA translocation specifically requires the presence of four additional Cag proteins. Here we show that the $\mathrm{CagA}$-binding protein $\mathrm{CagF}$ is a secretion chaperone-like protein that interacts with a 100 aa region that is adjacent to the $\mathrm{C}$-terminal secretion signal of $\mathrm{CagA}$. The interaction between CagA and CagF takes place at the bacterial cytoplasmic membrane, and is independent of a functional type IV secretion apparatus and other cag-encoded factors. Our data indicate that $\mathrm{CagF}$ binding precedes recognition of the C-terminal CagA translocation signal, and that both steps are required to recruit CagA to the type IV translocation channel.
\end{abstract}

\section{INTRODUCTION}

Helicobacter pylori, a Gram-negative bacterium that efficiently colonizes the human stomach, is one the most common infectious agents and can be considered as a model for microbial persistence (Blaser \& Atherton, 2004). Persistent colonization is the outcome of a complex interaction pattern with host tissues and the host immune system, comprising both bacterial and host factors. Two of the most important bacterial factors that are thought to contribute to the development of $H$. pylori-associated diseases are the vacuolating cytotoxin VacA and the cag pathogenicity island (PAI), which encodes a type IV secretion system (Blaser \& Atherton, 2004; Rieder et al., 2005a). Infection with type I $H$. pylori strains, which are defined by the presence of these virulence factors, is correlated with the development of more severe forms of disease, such as peptic ulcers, mucosa-associated lymphoid

Abbreviations: GFP, green fluorescent protein; GSK, glycogen synthase kinase; GST, glutathione S-transferase; IL-8, interleukin-8; PAl, pathogenicity island. tissue (MALT) lymphoma and adenocarcinoma (Suerbaum \& Michetti, 2002; Peek \& Blaser, 2002).

Type IV secretion systems are used by several Gramnegative bacterial pathogens to inject proteins directly into the cytoplasm of host cells, thereby to modulate important cellular functions (Fischer et al., 2002; Cascales \& Christie, 2003; Christie et al., 2005). The Cag type IV secretion system has been shown to translocate the bacterial CagA protein into host cells (Odenbreit et al., 2000), where it is tyrosine-phosphorylated and subsequently induces cytoskeletal rearrangements that either require, or are independent of, tyrosine phosphorylation (reviewed in Bourzac \& Guillemin, 2005; Backert \& Meyer, 2006). Moreover, CagA translocation results in signal transduction events that lead, for example, to proliferation defects in B lymphocytes or epithelial cells (Umehara et al., 2003; Yokoyama et al., 2005). Another cellular response caused by the Cag secretion system is the production and secretion of interleukin-8 (IL-8) by epithelial cells, which is independent of the CagA protein in some $H$. pylori strains but considerably enhanced by CagA in others (Fischer et al., 2001b; Viala et al., 2004; Brandt et al., 2005). In the 
Mongolian gerbil model, the Cag system and the CagA protein have been implicated in the development of a corpus-predominant gastritis, which is considered to be a precancerous condition (Rieder et al., 2005b). One process involved might be the CagA-dependent activation and nuclear accumulation of $\beta$-catenin (Franco et al., 2005).

The molecular mechanisms of CagA translocation are only poorly understood. Since the Cag type IV secretion system is only distantly related to prototypical systems, such as the VirB/D4 system of Agrobacterium tumefaciens, considerable differences in the mechanistic details of translocation are likely to occur. Recent studies have shown that most type IV-secreted effector proteins have C-terminal secretion signals that are necessary and sufficient for translocation, although recognition of these signals may be modulated by the presence of other domains (Vergunst et al., 2005; Schulein et al., 2005; Nagai et al., 2005). In contrast, the Cterminal CagA region is not sufficient to direct CagA translocation, although it has similar properties (Hohlfeld et al., 2006). Recognition of effector proteins as type IV substrates and their recruitment to the secretion apparatus are thought to be achieved by the so-called coupling proteins (Gilmour et al., 2003; Llosa et al., 2003; Atmakuri et al., 2003). Apart from the secretion apparatus and the coupling protein, additional factors are required for translocation of a subset of effector proteins. For example, the stability and secretion of the A. tumefaciens VirB/D4 effector protein VirE2 both depend on the secretion chaperone VirE1 (Sundberg et al., 1996; Sundberg \& Ream, 1999; Deng et al., 1999; Zhou \& Christie, 1999; Zhao et al., 2001), although other VirB/D4 effector proteins do not seem to require secretion chaperones. Likewise, cytosolic complexes of the IcmW, IcmS and LvgA proteins, which are also considered to be chaperone-like molecules, play an important role in type IV translocation of a subset of $\mathrm{Icm} /$ Dot effector proteins in Legionella pneumophila (Ninio et al., 2005; Bardill et al., 2005; Vincent \& Vogel, 2006). In type III secretion systems, which are also able to directly inject effector proteins into target cells, secretion chaperones function by maintaining effector protein stability, preventing premature interactions, or contributing to translocation channel targeting (Parsot et al., 2003; Ghosh, 2004). It has been suggested that chaperonedependent effector proteins are translocated with a higher priority in these systems.

The Cag type IV secretion system contains 18 gene products that are essential for CagA translocation. However, only 14 gene products are thought to encode components of the secretion apparatus, since besides their involvement in CagA translocation they are necessary for induction of IL-8 secretion from epithelial cells (Fischer et al., 2001b). The four additional proteins that are specifically necessary for CagA translocation include the coupling protein homologue $\mathrm{Cag} \beta$ (HP524) and the CagF (HP543) protein, which has been shown to interact with CagA in the bacterial cell (Couturier et al., 2006). Here we show that CagF functions as a secretion chaperone-like molecule that binds at the bacterial cytoplasmic membrane to a region near the $\mathrm{C}$ terminus of the effector protein CagA and thus adjacent to its C-terminal translocation signal.

\section{METHODS}

Bacterial strains, cell lines and culture conditions. $H$. pylori strains were grown on GC agar plates (Remel) supplemented with vitamin $\operatorname{mix}(1 \%)$, horse serum $(8 \%)$, vancomycin $\left(10 \mathrm{mg} \mathrm{l}^{-1}\right)$, trimethoprim $\left(5 \mathrm{mg} \mathrm{l}^{-1}\right)$ and nystatin $\left(1 \mathrm{mg} \mathrm{l}^{-1}\right)$ (serum plates), and incubated for $16-40 \mathrm{~h}$ in a microaerobic atmosphere $\left(85 \% \mathrm{~N}_{2}, 10 \%\right.$ $\mathrm{CO}_{2}, 5 \% \mathrm{O}_{2}$ ) at $37{ }^{\circ} \mathrm{C}$. Escherichia coli strains Top 10 (Invitrogen) and $\mathrm{DH} 5 \alpha$ (BRL) were grown on Luria-Bertani (LB) agar plates or in LB liquid medium (Sambrook et al., 1989) supplemented with ampicillin (100 $\left.\mathrm{mg} \mathrm{l}^{-1}\right)$, chloramphenicol $\left(30 \mathrm{mg} \mathrm{l}^{-1}\right)$ or kanamycin (40 $\mathrm{mg} \mathrm{l}^{-1}$ ), as appropriate. AGS gastric carcinoma cells were cultivated under standard conditions, as described previously (Odenbreit et al., 2000).

Plasmid constructs. Plasmids pJP89A, pSO174 and pJP55, which were used to generate isogenic cagY or cagF mutants, or to express $\operatorname{cag} A$ from a shuttle plasmid (Table 1), have been described previously (Odenbreit et al., 2000; Fischer et al., 2001b). For the construction of a $g s k-c a g F$ fusion, $c a g F$ without a start codon was amplified by PCR from chromosomal DNA of $H$. pylori strain 26695, using oligonucleotides WS215 and WS216 (Table 2), and cloned into the BglII and KpnI sites of plasmid pWS231 (Hohlfeld et al., 2006), resulting in plasmid pIP15. Plasmid pWS214 was constructed by cloning the same PCR fragment into plasmid pWS210 (Hohlfeld et al., 2006) and subsequent subcloning of the $m 45-c a g F$ gene fusion into the ClaI and SacI sites of the shuttle vector pHel3. Plasmid pIP31 was constructed by cloning a DNA fragment obtained by PCR with primers WS286 and WS287 into the SpeI and BglII sites of plasmid pWS122, and subsequent subcloning of the cagF-gfp fusion into the SalI and KpnI sites of the chromosomal integration vector pJP99. The construction of plasmids pIP8, pIP9, pIP9-2, pIP22, pWS231 and pWS252, encoding glycogen synthase kinase (GSK)-tagged CagA variants, and of plasmid pWS159-21 encoding a C-terminal CagA truncation variant, has been described previously (Hohlfeld et al., 2006). Plasmid pWS274 was constructed by PCR amplification of a $g s k-c a g A$ fragment from plasmid pIP9 using primers WS158 and WS318 and cloning into the ClaI and BamHI sites of pWS231. For the production of a glutathione $S$-transferase (GST)-CagF fusion protein, the $\operatorname{cagF}$ gene was amplified by PCR from strain 26695 using primers WS221 and WS222, and cloned into the BamHI and XhoI sites of pGEX4T-3 (Amersham Pharmacia Biosciences), resulting in plasmid pWS226. Similarly, the cagA gene was amplified from strain P12 using primers WS315 and HK3, and cloned into the BamHI and XhoI sites of pGEX4T-3, resulting in plasmid pRL1. For the construction of plasmid pIP32, the $g s k-c a g F$ fusion was subcloned from plasmid pIP15 into the EcoRI and KpnI sites of pCDFDuet-1 (Novagen). Plasmids pRL2 and pRL4, encoding fusions of green fluorescent protein (GFP) to the C-terminal 50 and 100 amino acids of CagA, respectively, were constructed by PCR amplification of $3^{\prime} \operatorname{cagA}$ regions using primer pairs WS316/JP67 or WS321/JP67, and cloning into the BglII and KpnI sites of plasmid pWS130. Plasmid pWS273, encoding GFP-CagA-195C, was obtained by cloning a 3' BglII/KpnI cagA fragment into the same sites of pWS130, and plasmid pRL3 is a BglII/BamHI deletion derivative of plasmid pWS130.

Bacterial transformation and conjugation. Shuttle plasmids and suicide plasmids were introduced into $H$. pylori strains by conjugation or transformation, as described previously (Haas et al., 1993; Fischer \& Haas, 2004). H. pylori transformants were selected on serum agar plates containing $6 \mathrm{mg}$ chloramphenicol $1^{-1}$ or $8 \mathrm{mg}$ kanamycin $1^{-1}$. 
Table 1. Plasmids used in this study

\begin{tabular}{|c|c|c|}
\hline Plasmid & Relevant characteristics & Source or reference \\
\hline pGEX4T-3 & gst fusion expression vector & Amersham Pharmacia \\
\hline pHel2 & Shuttle vector & Heuermann \& Haas (1998) \\
\hline pHel3 & Shuttle vector & Heuermann \& Haas (1998) \\
\hline pIP8 & pHel2, gsk-cagA (codons 1020-1214) & Hohlfeld et al. (2006) \\
\hline pIP9 & $\mathrm{pHel} 2, g s k-c a g A$ & Hohlfeld et al. (2006) \\
\hline pIP9-2 & pHel2, gsk-cagA (codons 1-702) & Hohlfeld et al. (2006) \\
\hline pIP15 & $\mathrm{pHel} 2$, gsk-cagF & This study \\
\hline pIP22 & pHel2, cagA (codons 1-613)-gsk & Hohlfeld et al. (2006) \\
\hline pIP31 & pJP99, cagF-gfp & This study \\
\hline pIP32 & pCDFDuet-1, $g s k-c a g F$ & This study \\
\hline pJP55 & pHel2, cagA (H. pylori 26695) & Odenbreit et al. (2000) \\
\hline pJP89A & $\mathrm{pBA}, \Delta h p 527::$ cat & Fischer et al. (2001b) \\
\hline pJP99 & Chromosomal integration plasmid & Püls et al. (2002) \\
\hline pRL1 & pGEX4T-3, cagA & This study \\
\hline pRL2 & pHel2, gfp-cagA (codons 1164-1214) & This study \\
\hline pRL3 & $\mathrm{pHel} 2, g f p$ & This study \\
\hline pRL4 & pHel2, $g f p-c a g A$ (codons 1114-1214) & This study \\
\hline pSO174 & $\mathrm{pBA}, \Delta h p 543:$ : cat & Fischer et al. (2001b) \\
\hline pWS122 & pHel2, $\operatorname{cag} A^{\prime}-g f p$ & Hohlfeld et al. (2006) \\
\hline pWS130 & pHel2, gfp-cagA (codons 614-1214) & Hohlfeld et al. (2006) \\
\hline pWS159-21 & pJP99, cagA (codons 1-1122) & Hohlfeld et al. (2006) \\
\hline pWS210 & pHel2, m45-cagA (codons 614-1214) & Hohlfeld et al. (2006) \\
\hline pWS214 & pHel3, m45-cagF & This study \\
\hline pWS226 & pGEX4T-3, cagF (H. pylori 26695) & This study \\
\hline pWS231 & pHel2, gsk-cagA (codons 614-1214) & Hohlfeld et al. (2006) \\
\hline pWS252 & pHel2, gsk-cagA (codons 1-1194) & Hohlfeld et al. (2006) \\
\hline pWS273 & pHel2, $g f p-c a g A$ (codons 1019-1214) & This study \\
\hline pWS274 & pHel2, gsk-cagA (codons 1-868) & This study \\
\hline
\end{tabular}

Production of GST fusion protein and GST pulldown assays. For the production and purification of GST-CagF fusion protein, overnight cultures of E. coli strain BL21 (DE3) containing plasmid pWS226 or pGEX4T-3 as a control were diluted in fresh LB medium and grown for $4 \mathrm{~h}$ at $37^{\circ} \mathrm{C}$ in a shaking incubator. Expression was induced by addition of IPTG to a final concentration of $0.2 \mathrm{mM}$, and

Table 2. Oligonucleotide primers used in this study

\begin{tabular}{|ll|}
\hline Primer & \multicolumn{1}{c|}{ Sequence $\left(\mathbf{5}^{\prime}-\mathbf{3}^{\prime}\right)^{*}$} \\
\hline HK3 & CGGGATCCGTCGACTTAAGATTTTTGGAAACCAC \\
JP67 & GGCCGAGCTCGGTACCTTAAGATTTTTGGAAACC- \\
& AC \\
WS158 & CCATCGATGGTAAAAATGTGAATCGT \\
WS215 & GAAGATCTTTGCGCGAACAAAAATTA \\
WS216 & GGGGTACCTCAATCGTTACTTTTTTT \\
WS221 & CGGGATCAAACAAAGTTTCGCGAAC \\
WS222 & ACCGCTCGAGTCAATCGTTACTTTTGTTT \\
WS286 & GGACTAGTTAGTAAGGAGTATTAAAATGAAAC \\
WS287 & GAAGATCTCCATCGTTACTTTTGTTTTGATT \\
WS315 & CAGGATCCACTAACGAAACCATTAACC \\
WS316 & GCAGATCTCACCAACTTGAACAACGCTG \\
WS318 & CGGGATCCGAAAAGTTTTAGAAAG \\
WS321 & GAAGATCTCATGCTAGCGCAAAAAAACCC \\
\hline
\end{tabular}

${ }^{\star}$ Restriction sites used for cloning are underlined. cells were grown for an additional $2 \mathrm{~h}$. Bacterial cells were harvested by centrifugation, resuspended in $50 \mathrm{mM}$ Tris/ $\mathrm{HCl}, \mathrm{pH}$ 7.4, containing protease inhibitors $\left(1 \mathrm{mM}\right.$ PMSF, $10 \mu \mathrm{g}$ leupeptin $\mathrm{ml}^{-1}, 10 \mu \mathrm{g}$ pepstatin $\mathrm{ml}^{-1}$ ), and lysed by two passages through a French pressure cell. The lysate was centrifuged for $15 \mathrm{~min}$ at $15000 \mathrm{~g}$ to remove insoluble material, and the supernatant was subjected to affinity chromatography on glutathione Sepharose 4B (GE Amersham Pharmacia) according to the manufacturers' instructions. The GST fusion protein was allowed to bind to the affinity matrix for $30 \mathrm{~min}$ at room temperature, and after three washes of the matrix with 10 bed volumes each of PBS, it was eluted in three fractions with $50 \mathrm{mM}$ Tris $/ \mathrm{HCl}, \mathrm{pH} 8.2,30 \mathrm{mM}$ reduced glutathione for $15 \mathrm{~min}$ each at room temperature.

For GST pulldown assays, glutathione Sepharose 4B was washed with PBS, then $200 \mu \mathrm{g}$ purified GST or GST-CagF was added to a $100 \mu \mathrm{l}$ bed volume of glutathione Sepharose and incubated at room temperature for $1 \mathrm{~h}$. Excess protein was removed by three washes with PBS containing protease inhibitors. Cleared bacterial lysates obtained by sonication and subsequent centrifugation were added and the mixture was incubated overnight at $4{ }^{\circ} \mathrm{C}$. After three washes with PBS, GST fusions and bound proteins were eluted three times with $50 \mathrm{mM}$ Tris/ $\mathrm{HCl}, \mathrm{pH} 8.0$, containing $10 \mathrm{mM}$ reduced glutathione, and analysed by immunoblotting.

Antisera, SDS-PAGE and immunoblotting. For the generation of the rabbit polyclonal CagF antiserum AK284, the purified GST-CagF fusion protein was proteolytically processed for $12 \mathrm{~h}$ at $4{ }^{\circ} \mathrm{C}$ with thrombin (1000 U; GE Amersham Pharmacia). CagF was subsequently separated from GST and thrombin by chromatography on 
benzamidine Sepharose (GE Amersham Pharmacia) and glutathione Sepharose 4B according to the manufacturer's instructions, and recovered in $50 \mathrm{mM}$ Tris/ $\mathrm{HCl}, \mathrm{pH} 7.4$, containing $150 \mathrm{mM} \mathrm{NaCl}$. The pooled fractions containing purified $\mathrm{CagF}$ were used to raise the rabbit antiserum AK284. Antisera AK257, directed against a Cterminal CagA domain, AK263, directed against $H$. pylori RecA, and anti-CagX (JHP477) have been described previously (Odenbreit et al., 2000; Fischer \& Haas, 2004). The GST antiserum was obtained from Sigma (monoclonal anti-GST, clone GST-2). For immunoprecipitation, antisera were purified on protein G-Sepharose, as described previously (Rohde et al., 2003).

SDS-PAGE and Western blotting were performed as described previously (Fischer et al., 2001b). For visualization of proteins after SDS-PAGE, gels were stained with Coomassie brilliant blue R250 or with silver stain (Blum et al., 1987). For the development of immunoblots, PVDF filters were blocked with $3 \%$ BSA in TBS (50 mM Tris/HCl, pH 7.5, $150 \mathrm{mM} \mathrm{NaCl}$ ) and incubated with the respective antisera at a dilution of $1: 1000-1: 5000$. Alkaline phosphatase-conjugated protein A or horseradish peroxidaseconjugated anti-rabbit IgG was used to visualize bound antibody.

Immunoprecipitation. Bacteria grown on agar plates were suspended in PBS and washed twice. Bacteria $\left(5 \times 10^{10}\right)$ were resuspended in radioimmunoprecipitation (RIPA) buffer $(50 \mathrm{mM}$ Tris/HCl, pH 8.0, $150 \mathrm{mM} \mathrm{NaCl}, 1 \mathrm{mM}$ EDTA, $1 \%$ Nonidet P-40, $0.25 \%$ sodium deoxycholate, $1 \mathrm{mM}$ PMSF, $10 \mu \mathrm{g}$ leupeptin $\mathrm{ml}^{-1}$, $10 \mu \mathrm{g}$ pepstatin $\mathrm{ml}^{-1}$ ) and the cells were lysed by sonication. Unbroken cells were removed by centrifugation for $10 \mathrm{~min}$ at $10000 \mathrm{~g}$. A $5 \mu \mathrm{l}$ volume of the appropriate antiserum was added to the supernatant, and samples were incubated for $3 \mathrm{~h}$ at $4{ }^{\circ} \mathrm{C}$. Then $50 \mu$ of prewashed protein $\mathrm{G}$-agarose (Roche Diagnostics) was added and samples were incubated at $4{ }^{\circ} \mathrm{C}$ for an additional $2 \mathrm{~h}$. After three washing steps with RIPA buffer, proteins were eluted with $100 \mathrm{mM}$ glycine, $\mathrm{pH} 2.7$, or by boiling in SDS-PAGE sample solution.

Determination of IL-8 secretion. The production of IL-8 by AGS cells after infection with $H$. pylori strains for $4 \mathrm{~h}$ was determined from cell supernatants by sandwich ELISA, as described previously (Fischer et al., 2001b).

Tyrosine phosphorylation and GSK phosphorylation assays. Standard infections of AGS cells with $H$. pylori strains and subsequent preparation for phosphotyrosine immunoblotting were performed as described previously (Odenbreit et al., 2000). Briefly, cells were infected with bacteria at an m.o.i. of 100 for $4 \mathrm{~h}$ at $37{ }^{\circ} \mathrm{C}$. After examination of cell morphology by light microscopy, cells were washed three times and suspended in PBS containing $1 \mathrm{mM}$ EDTA, $1 \mathrm{mM} \mathrm{Na}_{3} \mathrm{VO}_{4}, 1 \mathrm{mM}$ PMSF, $10 \mu \mathrm{g}$ leupeptin $\mathrm{ml}^{-1}$ and $10 \mu \mathrm{g}$ pepstatin $\mathrm{ml}^{-1}$. Cells with adherent bacteria were collected by centrifugation and resuspended in sample solution. For the determination of serine phosphorylation of the GSK tag, cells were infected and harvested as above, except that phosphatase inhibitor cocktail 1 (Sigma) was added to the suspension buffer. Tyrosine-phosphorylated proteins were analysed by immunoblotting with the phosphotyrosine antiserum PY99 (Santa Cruz Biotechnologies), and GSK phosphorylation was assayed by immunoblotting with phospho-GSK-3 $\beta$-specific antiserum 9336 (Cell Signaling Technology). As controls, the lysates were assayed for CagA production using antiserum AK257 (Odenbreit et al., 2000), or for GSK tag production using the GSK-3 $\beta$-specific antiserum 9332 (Cell Signaling Technology). An in vitro GSK phosphorylation assay was performed as described previously (Hohlfeld et al., 2006).

Analytical gel filtration chromatography. To determine the native molecular masses of CagF and the CagA-CagF complex, E. coli BL21 (DE3) containing either plasmid pWS226 or plasmids pRL1 and pIP32 was cultured and expression was induced as described above.
The GST-CagF fusion protein, or the complex of GST-CagA and GSK-CagF, was purified by affinity chromatography on glutathione Sepharose 4B, as described above, and CagF, or the complex of CagA and GSK-CagF, respectively, was released by thrombin cleavage and recovered in $50 \mathrm{mM}$ Tris/HCl, pH 7.5, $150 \mathrm{mM} \mathrm{NaCl}$. After highspeed centrifugation (45000 g, $45 \mathrm{~min}$ ), purified CagF was applied to a Superdex 75 column with a bed volume of $1.2 \mathrm{ml}$ operated by a SMART chromatography system (Amersham Biosciences) and equilibrated with the same buffer. Beginning with the exclusion volume, $25 \mu \mathrm{l}$ fractions were collected and analysed by CagF immunoblotting. Molecular masses were estimated using a Gel Filtration LMW Calibration kit (Amersham Biosciences). Similarly, purified CagA/GSK-CagF was applied to a Superdex 200 column operated by a SMART system, and fractions were analysed by CagA and CagF immunoblotting. Molecular masses were estimated using a Gel Filtration HMW Calibration kit (Amersham Biosciences).

\section{RESULTS}

\section{CagF is a translocation factor for CagA, but is not translocated by the type IV apparatus}

We have previously shown that a cagF ( $h p 543)$ mutant of H. pylori strain 26695 has a defect in CagA translocation but is still competent for induction of IL-8 from epithelial cells. Since the IL-8 phenotype is thought to depend on a functional type IV secretion apparatus, we concluded that CagF, like other cag-encoded proteins (CagI/HP540, CagZ/ HP526 and $\mathrm{Cag} /$ /HP524), is not a component of the type IV secretion apparatus but is specifically required as a CagA translocation factor (Fischer et al., 2001b). To confirm this result in a different strain background, we generated isogenic cagF and cagY mutants in $H$. pylori strain $\mathrm{P} 12$, a strain in which IL-8 induction is not completely independent of CagA translocation (Brandt et al., 2005), and tested these mutants for their ability to induce IL-8 secretion and translocate CagA. As expected, the cagY mutant of strain P12, lacking an essential component of the Cag secretion apparatus, was defective in IL-8 induction from AGS cells (Fig. 1a). In contrast to the cagF mutant in strain 26695, the P12 cagF mutant showed a decreased ability to induce IL- 8 secretion, reaching values of only about $65 \%$ of those of the wild-type strain. Consistently, IL-8 induction of an isogenic cagA mutant of strain P12 also reached levels of only about $62 \%$ of that of the wildtype (Fig. 1a). To investigate this phenotype further, we complemented the P12 $\Delta$ cagF mutant with plasmid pIP31, expressing a fusion of $c a g F$ and $g f p$. The complemented strain showed restored IL-8 induction levels (Fig. 1a). Furthermore, the P12 1 cagF mutant was defective in CagA translocation to epithelial cells, as shown by CagA tyrosine phosphorylation, and this phenotype could also be restored by complementation with cagF-gfp (Fig. 1b). To confirm this finding, cells infected with the different strains were examined for induction of the hummingbird phenotype, a characteristic cell elongation which depends on the presence of phosphorylated CagA inside the epithelial cell (Segal et al., 1999). The P12 $\Delta$ cagF mutant was unable to induce a hummingbird phenotype, whereas $\mathrm{P} 12 \Delta c a g F$ complemented 
(a)

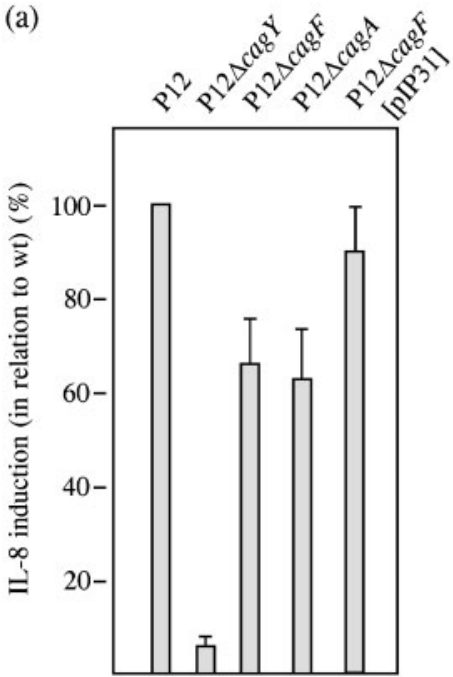

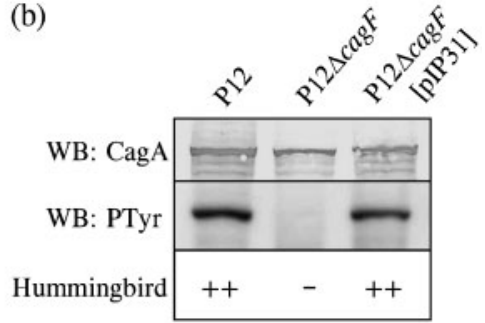

(c)

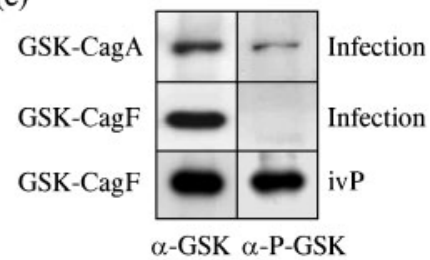

Fig. 1. CagF functions as a CagA translocation factor but is not a type IV effector protein. (a) AGS cells were infected with $H$. pylori wildtype (wt) strain P12 and isogenic mutants lacking the $\operatorname{cag} Y$, cag $F$ or $\operatorname{cag} A$ genes, and culture supernatants were assayed for IL-8 secretion using sandwich ELISA. Furthermore, the cagF mutant was complemented with plasmid pIP31, expressing a cagF-gfp fusion. All data are shown as mean and SD of at least three independent experiments. (b) Tyrosine phosphorylation assay of AGS cells infected for $4 \mathrm{~h}$ with $\mathrm{P} 12$, its isogenic cag $F$ mutant, or the cagF mutant complemented with plasmid pIP31. CagA tyrosine phosphorylation was determined by immunoblotting [Western blotting (WB)] using the phosphotyrosine antiserum PY99. Induction of the hummingbird phenotype was assayed microscopically and is indicated as strong $(++)$ or absent $(-)$. (c) AGS cells infected with $H$. pylori strains producing GSK-tagged CagA or CagF proteins were lysed and assayed for the presence of translocated proteins by immunoblotting against the GSK tag and phosphorylated GSK. As a control to show the accessibility of the GSK tag in the GSK-CagF fusion, H. pylori and AGS cell lysates were mixed and incubated in an in vitro phosphorylation assay (ivP). with pIP31 showed the same amount of elongated cells as the wild-type (Fig. 1b). These data clearly demonstrate that CagF is required for CagA translocation, but not for CagAindependent type IV-associated functions.

To exclude the possibility that $\mathrm{CagF}$ is co-translocated with CagA into epithelial cells and is required there for CagA tyrosine phosphorylation, we constructed a fusion of the phosphorylatable GSK-3 $\beta$ reporter tag (Hohlfeld et al., 2006; Torruellas-Garcia et al., 2006) to the $\mathrm{N}$ terminus of CagF. Production of GSK-tagged proteins in $H$. pylori is assessed by immunoblotting using an anti-GSK-3 $\beta$ antiserum, and translocation of these proteins into AGS cells by measuring serine phosphorylation of the GSK tag (Fig. 1c). While the GSK tag was phosphorylated in the GSK-CagA fusion protein after infection, no GSK phosphorylation could be detected in GSK-CagF. Since the GSK reporter tag is phosphorylated both at the cytoplasmic membrane and in the cytoplasm (TorruellasGarcia et al., 2006), and thus detects translocated proteins in both locations, this strongly suggests that CagF is not translocated to AGS cells.

\section{CagF interacts with CagA independently of other translocation factors or the secretion apparatus}

Translocation factors would be expected to interact with their cognate substrates, and possibly also with specific secretion apparatus components. To identify proteins encoded on the cag PAI that interact with CagA, we immunoprecipitated CagA from total cell lysates of the wild-type $H$. pylori strain $\mathrm{P} 12$, its isogenic cagA deletion mutant and an isogenic strain lacking the complete cag PAI, but expressing cagA from a shuttle plasmid (pJP55). The only prominent protein that coprecipitated with CagA in the wild-type strain, but not in the cagA mutant or in the cagA-expressing $\triangle \mathrm{PAI}$ mutant, had an apparent molecular mass of $\sim 35 \mathrm{kDa}$ (Fig. 2a). Immunoblotting identified this protein as $\mathrm{CagF}$, which has been shown elsewhere to interact with CagA (Couturier et al., 2006) (Fig. 2b). Since this interaction has also been found in a yeast two-hybrid assay (S. Kutter and W. Fischer, unpublished data), and can be demonstrated in E. coli by immunoprecipitation (Couturier et al., 2006), it is a very strong and direct interaction. To test whether the interaction in $H$. pylori depends on the presence of other cag-encoded factors, notably the coupling protein homologue $\operatorname{Cag} \beta$, we performed immunoprecipitation experiments on the $\mathrm{cag} V$ ( $h p 530$ ) mutant of strain 26695, with $\mathrm{CagV}$ representing an essential secretion apparatus component, and on the cagI ( $h p 540), \operatorname{cag} Z$ ( $h p 526)$ and $\operatorname{cag} \beta$ ( $h p 524)$ mutants, which lack genes encoding further CagA translocation factors (Fischer et al., 2001b; Buhrdorf et al., 2003). However, the amount of $\mathrm{CagF}$ coprecipitating with CagA was unchanged in these mutants (Fig. 2c, d and data not shown), 
(a)

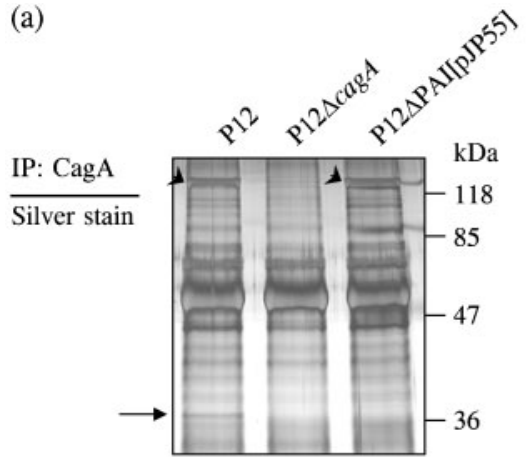

(c)

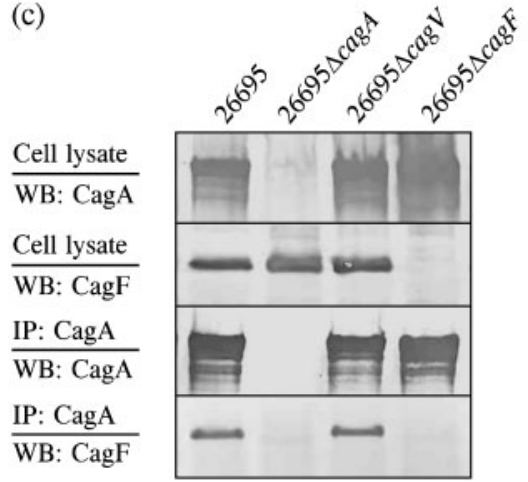

(b)

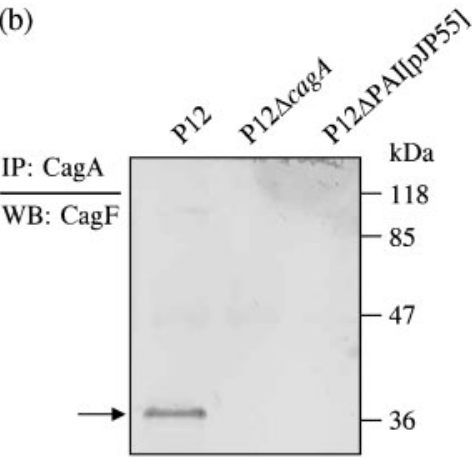

(d)

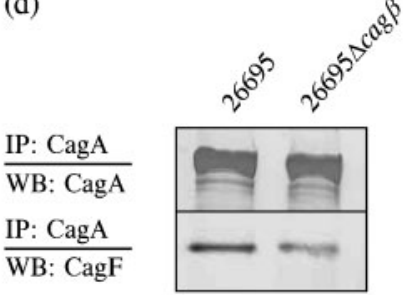

Fig. 2. $\mathrm{CagF}$ is a prominent CagA interaction partner in $H$. pylori. (a) In order to identify CagA-interacting proteins encoded on the cag PAl, CagA immunoprecipitation (IP) was performed from the wild-type strain $\mathrm{P} 12$, its isogenic cagA mutant and a P12 mutant expressing cag $A$ from a shuttle plasmid, but lacking the complete PAI (P12 $\triangle$ PAI[pJP55]). Silver staining shows the precipitation of $\mathrm{CagA}$ (arrowheads) and a coprecipitating PAIencoded protein of about $35 \mathrm{kDa}$ (arrow). (b) Western blotting (WB) with the polyclonal CagF antiserum AK284 identifies this protein as CagF. (c) Immunoprecipitation experiments in H. pylori strain 26695 and isogenic mutants. CagA was immunoprecipitated from the wildtype strain 26695 and isogenic mutants in the $\operatorname{cag} A, \operatorname{cag} V$ and $\operatorname{cag} F$ genes. Starting extracts used for immunoprecipitation and immunoprecipitates were examined by Western blotting using CagA and CagF antisera. (d) Immunoprecipitation of CagA from strain 26695 and its isogenic $\operatorname{cag} \beta$ mutant. Precipitates were examined by Western blotting using CagA and CagF antisera. suggesting that the interaction is independent of a functional secretion apparatus and of the presence of translocation factors. Thus, CagF binding probably precedes recruitment of CagA to the secretion apparatus, which is consistent with a role for $\mathrm{CagF}$ as a chaperone-like molecule.

\section{CagF is localized at the bacterial cytoplasmic membrane}

In order to fulfil a secretion chaperone-like role, CagF would be expected to be localized in the bacterial cytoplasm. However, conflicting results have been obtained recently with respect to CagF localization in the cytoplasmic membrane or at the bacterial surface (Couturier et al., 2006; Seydel et al., 2002). Since we were unable to detect $\mathrm{CagF}$ at the bacterial surface by immunofluorescence using the CagF antiserum AK284 (data not shown), we analysed CagF localization in bacterial cell fractions. After subfractionation of $H$. pylori cells into membrane-bound and soluble proteins, we found CagF to be partly soluble and partly membrane-associated (Fig. 3a), as also shown elsewhere (Couturier et al., 2006). The total membrane fraction was subsequently extracted with $1 \%(\mathrm{w} / \mathrm{v})$ Triton $\mathrm{X}-100$, which is often used to solubilize cytoplasmic membrane proteins (Schnaitman, 1971; Nikaido, 1994). This procedure resulted in a partial release of CagF from the membrane fraction. An extraction behaviour similar to that of $\mathrm{CagF}$ was found for the cytoplasmic-membraneassociated protein Cag $\alpha$ and for the integral cytoplasmic membrane protein ComB8 (Hofreuter et al., 2003), whereas the putative outer-membrane proteins CagX and AlpB could not be extracted with Triton X-100 (Fig. 3a). Comparable results were also obtained by membrane extraction with $N$-lauroyl sarcosine (data not shown), confirming the findings of Couturier et al. (2006). To examine whether $\mathrm{CagF}$ is an integral or a peripheral membrane protein, we extracted a total membrane fraction with $1 \mathrm{M} \mathrm{NaCl}$. CagF and Cag $\alpha$ were extracted by this procedure (Fig. 3b), whereas the integral cytoplasmic membrane protein ComB8 was not extracted under the same conditions. Taken together, the most likely localization of CagF is both in the cytoplasm and peripherally associated with the cytoplasmic membrane.

Since a cagF-gfp fusion was able to functionally complement the cagF mutation, as determined by the ability of the complemented strains to translocate CagA (Fig. 1b), it is likely that the localization of CagF-GFP reflects the actual localization of CagF in the bacterial cell. In order to determine this localization, we examined an $H$. pylori strain producing CagF-GFP by confocal microscopy. Apart from an even distribution in the bacterial cytoplasm, probably reflecting the cytoplasmic pool of CagF, GFP fluorescence was mostly found in several distinct patches close to the bacterial membrane (Fig. 3c, left panel). The same staining pattern was observed when cagF-gfp was expressed in a $\operatorname{cag} A$ mutant (data not shown), whereas GFP alone showed a uniform fluorescence (Fig. 3c, right panel). Furthermore, the strong GFP fluorescence in strain P12 $\Delta$ cagF [pIP31] indicates that the CagF C terminus 
(a)

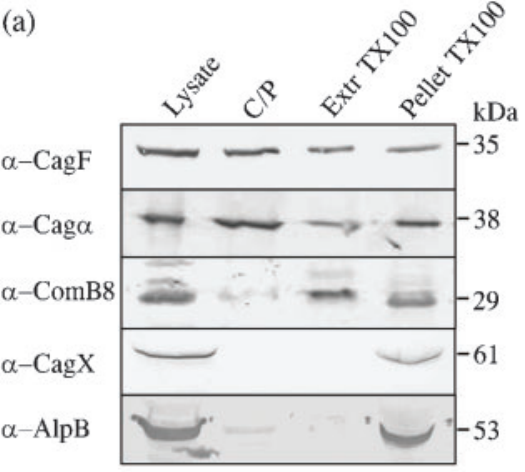

(b)

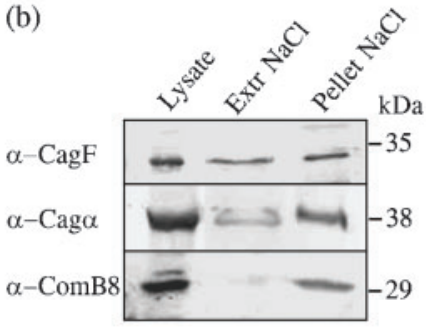

Fig. 3. Localization of $\mathrm{CagF}$ in the bacterial cell. (a) Cells of $H$. pylori strain P12 were lysed and separated by ultracentrifugation into a soluble fraction containing cytoplasmic and periplasmic proteins $(\mathrm{C} / \mathrm{P})$ and a total membrane fraction which was subsequently extracted with $1 \%$ Triton X-100. Triton X100-soluble proteins (Extr TX100) correspond to cytoplasmic membrane proteins, and Triton X-100-insoluble proteins (Pellet TX100) correspond to outer-membrane proteins. Immunoblots with the indicated antibodies $(\alpha-)$ were used to determine protein concentrations in the respective fractions. (b) To determine whether $\mathrm{CagF}$ is an integral or a peripheral membrane protein, the total membrane fraction was extracted with $1 \mathrm{M} \mathrm{NaCl}$. The soluble fraction $(\mathrm{C} / \mathrm{P})$, the $\mathrm{NaCl}$-extracted fraction (Extr $\mathrm{NaCl}$ ) and $\mathrm{NaCl}$-insoluble material (Pellet $\mathrm{NaCl}$ ) were assayed by immunoblotting against the indicated proteins. (c) Confocal fluorescence microscopy of $H$. pylori cells producing a functional CagF-GFP fusion protein from plasmid pIP31 (left panel) or GFP alone from plasmid pRL3 (right panel). (and therefore the complete protein) is localized at the cytoplasmic, and not the periplasmic, face of the inner membrane (Drew et al., 2002).

\section{CagF interacts with CagA at the cytoplasmic membrane, but is not responsible for CagA membrane targeting}

Since both CagF and CagA are found in membraneassociated and cytoplasmic pools, we were interested in where their interaction takes place. To investigate this, we fractionated an $H$. pylori cell lysate by ultracentrifugation into a membrane fraction and a soluble fraction and performed immunoprecipitations from both fractions independently. Although CagA and CagF were found in comparable amounts in both fractions, CagF mainly coprecipitated with CagA from the membrane fraction, and only in minor amounts from the soluble fraction (Fig. 4a). This suggests that CagA and CagF form a stable complex associated with the bacterial cytoplasmic membrane. We speculated that CagF might bind to CagA in the cytoplasm and then recruit it to the membrane. To test this, we prepared membrane and soluble fractions of the isogenic cagA and cagF mutants in strain 26695 and compared them with the wild-type strain. As shown in Fig. 4(b), deletion of $c a g F$ had no influence on CagA membrane association, and deletion of cagA had no influence on CagF membrane association either, indicating that both proteins target the membrane independently and that CagF thus does not have a membrane recruitment function for CagA.

\section{CagF forms homodimers and interacts with CagA as a complex of more than $200 \mathrm{kDa}$}

Since secretion chaperones in type III secretion systems often form dimers, we employed gel filtration chromatography to determine the size of purified CagF. For that purpose, we overexpressed a $g s t-c a g F$ fusion from plasmid pWS226 in E. coli, and purified GST-CagF by affinity chromatography on glutathione Sepharose 4B. CagF was eluted after cleavage of the GST moiety with thrombin, and applied to a Superdex 75 gel filtration column. From the gel filtration column, CagF eluted as two peaks centred at about 70 and $35 \mathrm{kDa}$, respectively, indicating that purified recombinant $\mathrm{CagF}$ exists in both a monomeric and a dimeric form (Fig. 5a). To estimate the size of the CagACagF complex, we coexpressed gst-cagA and gsk-cagF in E. coli from plasmids pRL1 and pIP32, purified the complex formed by both proteins on glutathione Sepharose $4 \mathrm{~B}$ and eluted the complex after thrombin cleavage. Size-exclusion chromatography was performed on a Superdex 200 column, and eluted fractions were tested for CagA and CagF content by immunoblotting. CagA eluted as a broad peak with the maximal concentration corresponding to an apparent molecular mass of 180-250 kDa (fractions 17-21; Fig. 5b). Minor amounts of CagA were also found in the range between 120 and $180 \mathrm{kDa}$ and at higher molecular masses, suggesting that several different oligomeric complexes containing CagA were present. In many fractions, CagA was partially processed to a major breakdown product of about $100 \mathrm{kDa}$, which is frequently encountered 

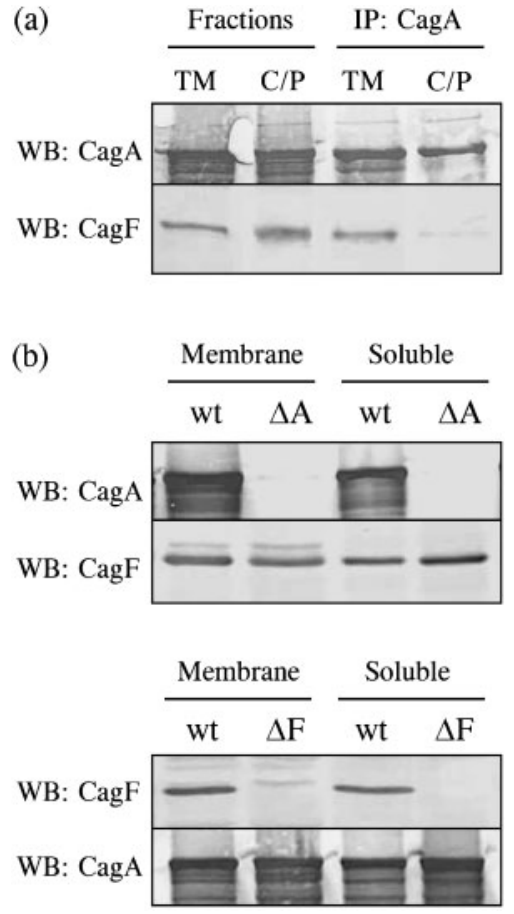

Fig. 4. Interaction of $\mathrm{CagA}$ and $\mathrm{CagF}$ takes place at the bacterial membrane, but CagF is not necessary for CagA membrane recruitment. (a) $H$. pylori cells were separated by ultracentrifugation into a total membrane fraction (TM) and a soluble fraction containing cytoplasmic and periplasmic proteins (C/P). CagA was immunoprecipitated from both fractions independently and the fractions and immunoprecipitates were assayed for CagA and CagF content by immunoblotting [Western blotting (WB)]. (b) Membrane preparations and soluble fractions from the 26695 wild-type strain (wt) and its isogenic $\operatorname{cag} A(\Delta \mathrm{A})$ and $\operatorname{cag} F(\Delta \mathrm{F})$ mutants were compared by immunoblotting with respect to membrane association of CagA and CagF.

after recombinant expression or during infection of phagocytic cells (Moese et al., 2001). The fractions with the highest concentrations of CagA also contained most of the CagF (Fig. 5b). Thus, CagF shifts from a molecular mass of 35 or $70 \mathrm{kDa}$, when produced alone, to a complex of $180-250 \mathrm{kDa}$ when CagA is present. Although the resolution of our gel filtration experiments was too low to determine the exact stoichiometry, this finding is consistent with the formation of complexes containing one fulllength CagA monomer (135 kDa) and two CagF (35 kDa) monomers.

\section{CagF interacts with a C-terminal CagA domain distinct from the putative translocation signal}

To delineate the CagA region that interacts with $\mathrm{CagF}$, we used a GST pulldown assay with recombinant GST-CagF fusion protein coupled to glutathione Sepharose beads. We incubated these beads with extracts of $H$. pylori mutants producing GSK-tagged full-length CagA or GSK-tagged
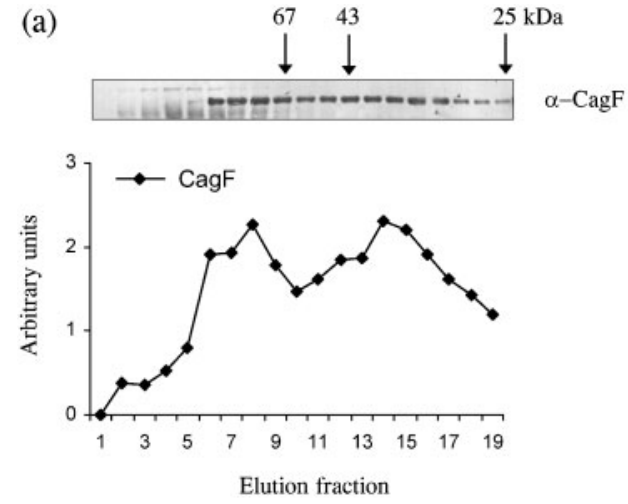

(b)
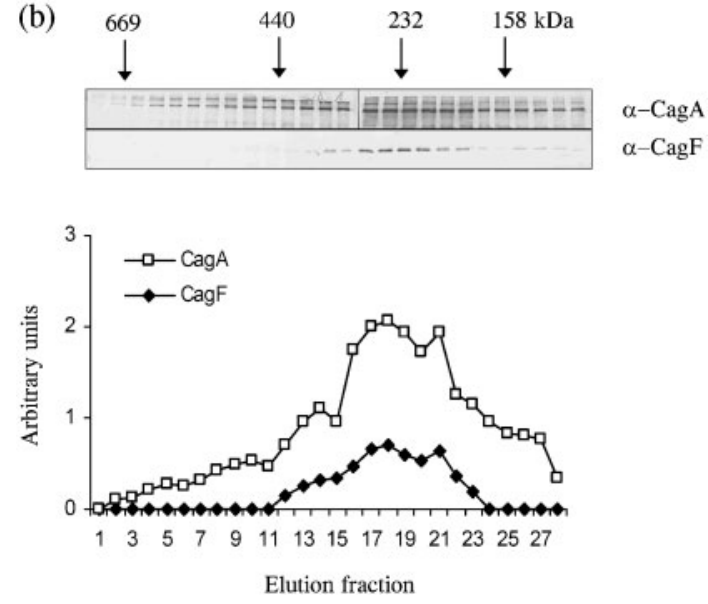

Fig. 5. Analytical gel filtration chromatography of purified recombinant CagF and a complex of CagA and GSK-CagF. (a) Purified CagF was obtained by thrombin cleavage of GST-CagF bound to glutathione Sepharose and applied to a Superdex 75 gel filtration column. Starting with the exclusion volume, fractions were collected and assayed for CagF content by immunoblotting and by densitometry. Arrows with molecular masses indicate the elution volumes of marker proteins. (b) A complex of CagA and GSK-CagF was purified by affinity chromatography on glutathione 4B from a lysate of an $E$. coli strain coexpressing gst-cagA and gsk-cag $F$ and subsequent thrombin cleavage. The purified complex was applied to a Superdex 200 gel filtration column, and fractions were collected starting from the exclusion volume, and assayed for $\mathrm{CagA}$ and $\mathrm{CagF}$ content by immunoblotting and densitometry. Arrows with molecular masses indicate the elution volumes of marker proteins.

truncation variants (Fig. 6a). All variants were soluble as determined by immunoblotting of high-speed centrifugation supernatants of the corresponding bacterial lysates (data not shown). Immunoblots of the pulldown fractions using an anti-GSK antiserum showed that GST-CagF bound to GSK-tagged full-length CagA, whereas GST alone did not bind (Fig. 6b). All CagA variants containing their C-terminal parts were also pulled down by GST-CagF, whereas no interaction with CagA variants containing only 
(a)

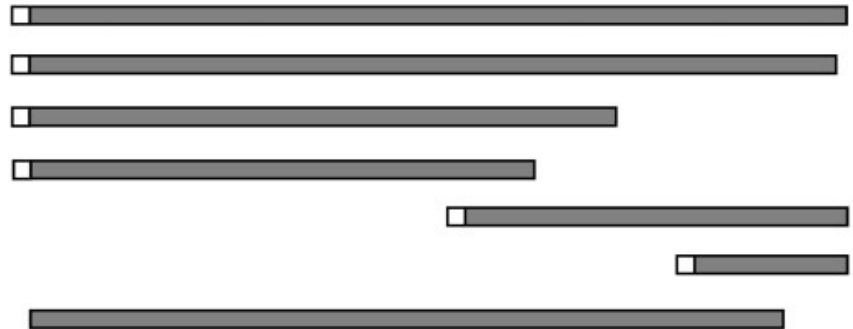

GSK-CagA

GSK-CagA $\Delta 20 \mathrm{C}$

GSK-CagA $\triangle 347 \mathrm{C}$

GSK-CagA $\triangle 512 \mathrm{C}$

GSK-CagA $\triangle 613 \mathrm{~N}$

GSK-CagA $\Delta 1019 \mathrm{~N}$

CagA $\Delta 92 \mathrm{C}$

(b)
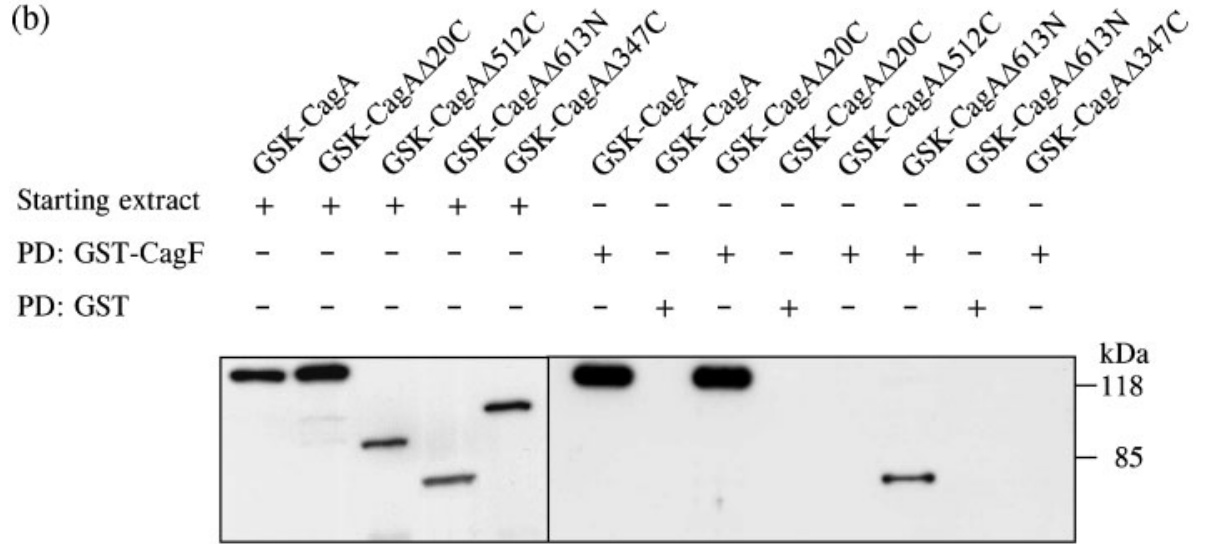

WB: GSK

WB: GSK

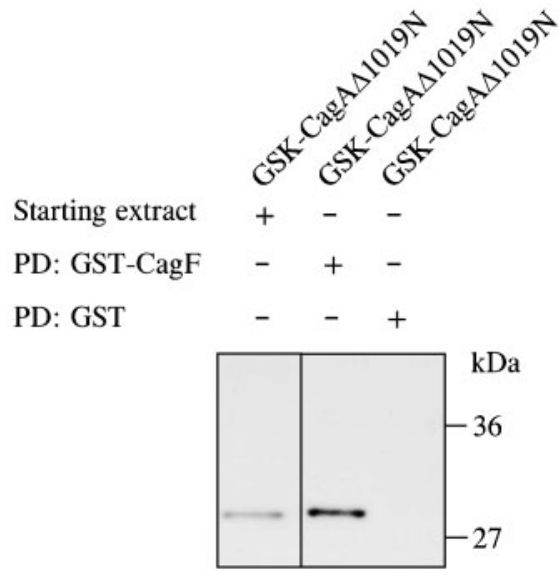

WB: GSK

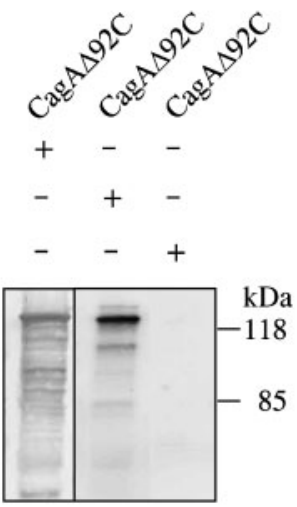

WB: CagA

Fig. 6. Delineation of the CagF-interacting region of the CagA protein. (a) Schematic representation of GSK-tagged and untagged CagA truncation variants used for GST-CagF pulldown assays. The number of amino acids deleted from the N or C terminus of CagA is indicated. (b) Cell extracts from $H$. pylori strains producing the respective CagA truncation variants were subjected to GST pulldown (PD) assays with GST-CagF and GST. Control immunoblots show the presence of comparable amounts of the CagA variants in the cell extracts. GSK or CagA immunoblots [Western blots (WB)] of the pulldown fractions obtained with GST-CagF or with GST alone indicate specific interactions of CagA variants with CagF.

N-terminal regions occurred (Fig. 6b). Notably, the CagA variant lacking 347 C-terminal amino acids, which corresponds to the major $100 \mathrm{kDa}$ breakdown product, was not pulled down, showing that $\mathrm{CagF}$ binds only to the C-terminal region of CagA, with the C-terminal 195 amino acids being sufficient for the interaction. Since the Cterminal CagA region contains an essential part of the translocation signal (Hohlfeld et al., 2006), one explanation would be that $\mathrm{CagF}$ acts as the main signal recognition protein. To test this possibility, we also performed GST- 
CagF pulldown assays with strains producing a GSK-tagged CagA variant lacking its $20 \mathrm{C}$-terminal amino acids, or an untagged CagA variant lacking $92 \mathrm{C}$-terminal amino acids, both of which are translocation-defective (Hohlfeld et al., 2006). Interestingly, both CagA variants were able to interact with GST-CagF in the pulldown assay (Fig. 6b), indicating that the CagF-binding domain is located between amino acids 1019 and 1123 of CagA. These data also suggest that $\mathrm{CagF}$ interaction with $\mathrm{CagA}$ is not sufficient for CagA recognition as a type IV substrate and that CagF binding is thus not the basic type IV signal recognition mechanism.

\section{The CagF-binding region is required for a dominant-negative effect of GFP-CagA fusion proteins}

Some secretion chaperones in type III secretion systems are thought to contribute to the translocation signals of their cognate effector proteins, targeting the effector proteins to the type III secretion apparatus (Cheng \& Schneewind, 1999; Lee \& Galan, 2004). The close proximity of the CagFbinding region to the $\mathrm{C}$-terminal CagA signal region might indicate a similar role for $\mathrm{CagF}$ in type IV secretion apparatus targeting. We have previously shown that a fusion of GFP to the C-terminal half of CagA (GFP-CagA601C) exerts a dominant-negative effect on wild-type CagA translocation (Hohlfeld et al., 2006). This phenotype was interpreted as an obstruction of the translocation channel by the rigid tertiary structure of GFP, which would mean that the CagA C-terminal domain contains a recruitment signal to the type IV secretion apparatus. In order to demonstrate a potential targeting function of the CagFbinding domain, we constructed a fusion of GFP to the Cterminal 195 amino acids of CagA, produced this fusion in a wild-type $H$. pylori background (strain P1), and examined translocation of wild-type CagA to AGS cells by measuring tyrosine phosphorylation. Intriguingly, the GFP-CagA-195C fusion interfered with wild-type CagA translocation in a fashion similar to the GFP-CagA-601C fusion protein (Fig. 7). In contrast, fusion proteins consisting of GFP and the C-terminal 50 or 100 amino acids of CagA, or GFP alone, did not interfere with wildtype CagA translocation, when produced in strain P1. These results suggest that the CagF-binding domain, together with the C-terminal CagA signal region, contains sufficient information to recruit CagA to the secretion apparatus.

\section{DISCUSSION}

Translocation of CagA evokes pronounced changes in host cell functions, such as an inactivation of Src-family kinases accompanied by protein dephosphorylation (Odenbreit et al., 2000; Selbach et al., 2003, 2004), a disturbance of epithelial tight junction integrity (Amieva et al., 2003), and massive rearrangements of the actin cytoskeleton that are

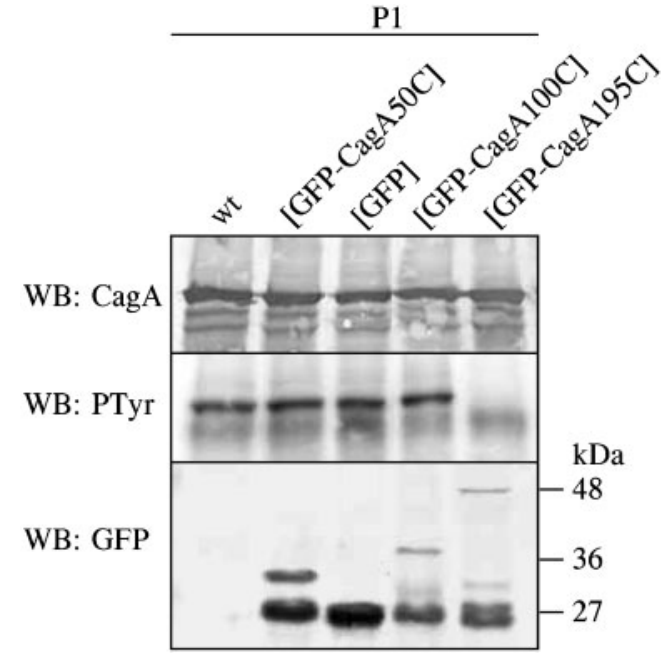

Fig. 7. Dominant-negative effects of GFP fusions to C-terminal CagA regions. Gene fusions of $g f p$ to $\operatorname{cag} A$ portions encoding the indicated numbers of $\mathrm{C}$-terminal amino acids, or gfp alone, were expressed in $H$. pylori wild-type (wt) strain P1. After standard infection of AGS cells, wild-type CagA translocation from the corresponding strains was determined by tyrosine phosphorylation. A CagA immunoblot [Western blot (WB)] of the same fractions indicates the presence of equal amounts of $\mathrm{CagA}$, and a GFP immunoblot shows the expression of the corresponding GFP-CagA fusion proteins.

apparent in cell culture as the so-called hummingbird phenotype or an induction of cell motility (Segal et al., 1999; Churin et al., 2003; Mimuro et al., 2002; Higashi et al., 2002, 2004; Suzuki et al., 2005). Moreover, host cells respond to CagA injection with altered signal transduction activities and modified gene expression patterns (Guillemin et al., 2002; Umehara et al., 2003; El Etr et al., 2004; Franco et al., 2005; Yokoyama et al., 2005). Accordingly, CagA injection into host cells has important consequences for host-bacterium interaction and would thus be expected to be subject to strict control. In line with this assumption is the observation that recognition of CagA as a substrate for type IV secretion seems to be more complex than recognition of other type IV substrates (Hohlfeld et al., 2006). Four proteins encoded on the cag PAI (CagF, CagI, CagZ and Cag $\beta$ ) are necessary for CagA translocation without being secretion apparatus components (Fischer et al., 2001b). The identification of CagF as a CagA-interacting protein (Couturier et al., 2006) and its characterization as a chaperone-like molecule support the notion of a quality control process prior to CagA translocation.

Secretion chaperones and chaperone-like molecules are involved in different types of protein secretion, but have been extensively characterized in type III secretion systems. In these systems, their function is to maintain the stability and secretion competence of effector proteins, e.g. by keeping them in an unfolded state, to prevent premature 
effector protein interactions and/or to recruit the effector proteins to the secretion apparatus (Parsot et al., 2003; Ghosh, 2004). In many cases, however, effector protein translocation is not strictly dependent on the presence of the secretion chaperone. For type IV secretion systems, a secretion chaperone function has been documented for the VirE1 protein of A. tumefaciens, which is necessary for translocation of the effector protein VirE2 into plant cells (Sundberg et al., 1996; Deng et al., 1999; Zhou \& Christie, 1999; Sundberg \& Ream, 1999; Zhao et al., 2001). The IcmS, IcmW and LvgA proteins of the L. pneumophila Icm/ Dot system, which are required for translocation of a subset of substrates and have also been termed 'type IV adaptor proteins' (Ninio et al., 2005; Bardill et al., 2005; Vincent \& Vogel, 2006), probably have a similar function. Several lines of evidence argue for a function of $\mathrm{CagF}$ as a secretion chaperone-like molecule for CagA:

(i) Like VirE1 and the L. pneumophila type IV adaptor proteins, CagF has typical features that are also common to type III secretion chaperones: it has an acidic isoelectric point (pI 4.5) and a high predicted content of $\alpha$-helical domains. However, with a size of $35 \mathrm{kDa}$, it is much larger than typical secretion chaperones, which usually have a molecular mass of less than $20 \mathrm{kDa}$. This unusual size may relate to the membrane-association properties of $\mathrm{CagF}$.

(ii) CagF is necessary for CagA translocation, but it is not required for IL-8 induction, which is thought to occur independently of CagA translocation, possibly by leakage of peptidoglycan fragments through the type IV secretion apparatus (Viala et al., 2004). In the case of H. pylori P12, which belongs to a subset of strains in which CagA has an ancillary IL-8-inducing function (Brandt et al., 2005), CagF is required only for the CagA-dependent fraction of the IL8 -inducing effect.

(iii) Like most secretion chaperones in type III secretion systems, CagF forms homodimers, and our gel filtration data are consistent with the formation of a $2: 1$ stoichiometry in the complex with CagA. The calculated size of a complex of one full-length CagA monomer and two $\mathrm{CagF}$ monomers would be $205 \mathrm{kDa}$, which corresponds quite well with the elution volume of the peak fractions. Since the CagA $\triangle 347 \mathrm{C}$ variant does not interact with $\mathrm{CagF}$, it is unlikely that the $100 \mathrm{kDa}$ CagA breakdown product found in these fractions participates in the CagACagF complexes. Secretion chaperones in type III secretion systems are known to also bind in a 2:1 chaperone: effector protein ratio via hydrophobic patches on the chaperone surface and hydrogen bonds (Ghosh, 2004). For type IV secretion systems, the oligomeric status of chaperone-like molecules is less clear. VirE1 binds to VirE2 with a 2:1 stoichiometry, although VirE1 itself seems to form tetramers rather than dimers (Zhao et al., 2001). In contrast, IcmS seems to form two different heterodimeric complexes with either IcmW or LvgA, which together may also form tetramers (Ninio et al., 2005; Vincent \& Vogel, 2006). (iv) The CagF-binding domain of the CagA protein is, together with the C-terminal secretion-signal-containing region, sufficient for the dominant-negative effect induced by GFP fusions. Since such dominant-negative effects do not occur with epitope tags such as the GSK tag fused to the same CagA regions (data not shown) they are unlikely to be caused simply by competition for CagF binding. Instead, they suggest a recruitment function for the Cterminal CagA region and thus a contribution of CagF to the targeting signal, as also suggested for some type III secretion chaperones (Cheng \& Schneewind 1999; Lee \& Galan, 2004).

Unlike typical secretion chaperones, $\mathrm{CagF}$ seems to be present in both soluble and membrane-associated pools. Although a clear separation of $H$. pylori membranes is not easily achieved by standard techniques, such as differential detergent extraction or sucrose-density-gradient centrifugation (Exner et al., 1995; Fischer et al., 2001a), our fractionation experiments indicate that $\mathrm{CagF}$ is most likely associated with the cytoplasmic membrane, as already suggested elsewhere (Couturier et al., 2006). The fluorescence of the CagF-GFP fusion and the extraction of CagF with $1 \mathrm{M} \mathrm{NaCl}$ suggest that $\mathrm{CagF}$ is peripherally associated with the cytoplasmic face of the inner membrane. The fact that $\mathrm{CagF}$ interacts with CagA primarily at the cytoplasmic membrane, and only to a very limited extent in the cytoplasm, indicates that the mechanism of action of CagF is very different from that of VirE1. VirE1 is a cytosolic protein that functions by regulating efficient translation of VirE2 (Zhao et al., 2001) and by preventing the formation of VirE2 aggregates (Deng et al., 1999; Zhao et al., 2001). In contrast, CagF does not seem to have a role in stabilizing CagA or preventing it from aggregation, since both the formation of higher order oligomers or aggregates and the processing of recombinant CagA produced in E. coli were independent of the presence or absence of CagF (data not shown). Furthermore, CagF is not necessary for CagA recruitment to the membrane, which is probably a prerequisite for type IV translocation. CagA membrane recruitment is also independent of any other cag-encoded factor, since its distribution between membrane-associated and soluble states was unchanged in the mutant P12 2 PAI[pJP55], which expresses cagA in a cag PAIdeficient background (data not shown). However, CagA interaction with the membrane might not be sufficient to target the secretion apparatus. The location of the site of assembly of the Cag secretion apparatus is currently unknown, although extracellular type IV-associated surface appendages are often found in a polar localization or along the lateral surface of bacteria (Rohde et al., 2003). The localization of the CagF-GFP fusion to the bacterial cell is reminiscent of the distribution of the Cag secretion apparatus components CagY and CagT over the bacterial surface (Rohde et al., 2003). Recently, an interaction between $\mathrm{CagF}$ and the cytoplasmic domain of $\mathrm{CagY}$ has been described (Busler et al., 2006), supporting the assumption that $\mathrm{CagF}$ is located in proximity to the Cag 
type IV secretion system. Thus, we speculate that interaction with $\mathrm{CagF}$ at the cytoplasmic membrane is a prerequisite for targeting CagA to type IV secretion apparatus assembly sites. This is also supported by the dominant-negative effect observed by fusion of GFP to the CagA C terminus including the CagF-binding region. Accordingly, interaction with $\mathrm{CagF}$ may contribute to the CagA targeting signal, as has been suggested for type III secretion chaperone-effector complexes such as the SycEYopE complex in Yersinia enterocolitica (Birtalan et al., 2002). VirE1, in contrast, is not necessary for the targeting of its cognate effector protein VirE2 to the VirB/D4 secretion apparatus (Atmakuri et al., 2003).

It is currently unknown which component recognizes CagA as a type IV secretion substrate. Recent investigations have shown that different type IV effector proteins have secretion signals at their C-terminal ends (Nagai et al., 2005; Vergunst et al., 2005; Schulein et al., 2005). Although a similar sequence is present at the CagA $\mathrm{C}$ terminus as well, the additional requirement for the CagA $\mathrm{N}$ terminus indicates that CagA recognition as a substrate is more complex than in other type IV secretion systems (Hohlfeld et al., 2006). Since the CagA N terminus is dispensable for the dominant-negative effect of GFP fusions, this suggests that a second binding or recognition step is necessary for translocation. Interestingly, the outer-membrane apparatus component VirB9 of A. tumefaciens has been reported to have such an additional substrate selectivity function (Jakubowski et al., 2005); however, the VirB/D4 system accomplishes substrate translocation with only 19 Cterminal amino acids, although less efficiently (Vergunst et al., 2005). The current hypothesis states that recognition of C-terminal type IV secretion signals and thus substrate specificity is mediated by the coupling proteins (GomisRüth et al., 2004; Christie et al., 2005; Cambronne \& Roy, 2006). After recognition by the coupling protein, substrates are transferred to the cognate ATPases of the VirB11 family (Cascales \& Christie, 2004; Atmakuri et al., 2004), which might represent the entry point into the translocation channel. Although there is no direct experimental evidence so far, the coupling protein homology of $\operatorname{Cag} \beta$ and its requirement for CagA translocation suggest a similar role for $\mathrm{Cag} \beta$ in $\mathrm{CagA}$ secretion signal recognition. Since CagA variants lacking 20,54 or 92 C-terminal amino acids are translocation-incompetent but still able to interact with $\mathrm{CagF}$, it is unlikely that $\mathrm{CagF}$ itself has a signal recognition function. The direct interaction of $\mathrm{CagA}$ and $\mathrm{CagF}$ in the absence of other CagA translocation factors or secretion apparatus components rather suggests that $\mathrm{CagF}$ binding is the first step in the process of CagA translocation and thus precedes recognition of the translocation signal. Nevertheless, CagF binding may increase the accessibility of the C-terminal secretion signal to the signal recognition factor or may keep the $\mathrm{C}$ terminus partially unfolded. It has been speculated that a disordered state of the $\mathrm{C}$ terminus is important for signal recognition in type IV secretion systems (Amor et al., 2005). Since we could not detect
GSK-CagF phosphorylation after AGS cell infection and since CagF did not coprecipitate with tyrosine-phosphorylated CagA from infected cells (data not shown), it is unlikely that $\mathrm{CagF}$ is translocated together with CagA to epithelial cells. Thus, we would expect that CagA entry into the translocation channel results in the release, and possibly recycling, of CagF.

Taken together, the results presented in this study confirm that recognition of CagA as a substrate for type IV secretion is a complex process and argue for a function of the translocation factor CagF as a CagA secretion chaperone-like molecule. They suggest that $\mathrm{CagF}$ binding might be a quality control mechanism that ensures the integrity or the correct folding of the CagA substrate prior to recognition of its translocation signal and entry into the translocation channel. Further studies are required to elucidate the molecular details of this critical step in $H$. pylori pathogenesis.

\section{ACKNOWLEDGEMENTS}

We thank Emilia Sieger for purification of the GST fusions, Christian Giller for help with generation of the CagF antiserum, Jürgen Püls for generating $H$. pylori strain P12 2 PAI[pJP55], and Luisa F. JiménezSoto for numerous helpful discussions. This work was supported by research grants from the Deutsche Forschungsgemeinschaft (FI 953/11; FI 953/1-2) to W.F.

\section{REFERENCES}

Amieva, M. R., Vogelmann, R., Covacci, A., Tompkins, L. S., Nelson, W. J. \& Falkow, S. (2003). Disruption of the epithelial apical-junctional complex by Helicobacter pylori CagA. Science 300, 1430-1434.

Amor, J. C., Swails, J., Zhu, X., Roy, C. R., Nagai, H., Ingmundson, A., Cheng, X. \& Kahn, R. A. (2005). The structure of RalF, an ADPribosylation factor guanine nucleotide exchange factor from Legionella pneumophila, reveals the presence of a cap over the active site. J Biol Chem 280, 1392-1400.

Atmakuri, K., Ding, Z. \& Christie, P. J. (2003). VirE2, a type IV secretion substrate, interacts with the VirD4 transfer protein at cell poles of Agrobacterium tumefaciens. Mol Microbiol 49, 1699-1713.

Atmakuri, K., Cascales, E. \& Christie, P. J. (2004). Energetic components VirD4, VirB11 and VirB4 mediate early DNA transfer reactions required for bacterial type IV secretion. Mol Microbiol 54, 1199-1211.

Backert, S. \& Meyer, T. F. (2006). Type IV secretion systems and their effectors in bacterial pathogenesis. Curr Opin Microbiol 9, 207-217.

Bardill, J. P., Miller, J. L. \& Vogel, J. P. (2005). IcmS-dependent translocation of SdeA into macrophages by the Legionella pneumophila type IV secretion system. Mol Microbiol 56, 90-103.

Birtalan, S. C., Phillips, R. M. \& Ghosh, P. (2002). Three-dimensional secretion signals in chaperone-effector complexes of bacterial pathogens. Mol Cell 9, 971-980.

Blaser, M. J. \& Atherton, J. C. (2004). Helicobacter pylori persistence: biology and disease. J Clin Invest 113, 321-333.

Blum, H., Beier, H. \& Gross, H. J. (1987). Improved silver staining of plant proteins, RNA and DNA in polyacrylamide gels. Electrophoresis 8, 93-99. 
Bourzac, K. M. \& Guillemin, K. (2005). Helicobacter pylori-host cell interactions mediated by type IV secretion. Cell Microbiol 7, 911-919.

Brandt, S., Kwok, T., Hartig, R., König, W. \& Backert, S. (2005). NF$\kappa \mathrm{B}$ activation and potentiation of proinflammatory responses by the Helicobacter pylori CagA protein. Proc Natl Acad Sci U S A 102, 9300-9305.

Buhrdorf, R., Förster, C., Haas, R. \& Fischer, W. (2003). Topological analysis of a putative virB8 homologue essential for the cag type IV secretion system in Helicobacter pylori. Int J Med Microbiol 293, 213-217.

Busler, V. J., Torres, V. J., McClain, M. S., Tirado, O., Friedman, D. B. \& Cover, T. L. (2006). Protein-protein interactions among Helicobacter pylori Cag proteins. J Bacteriol 188, 4787-4800.

Cambronne, E. D. \& Roy, C. R. (2006). Recognition and delivery of effector proteins into eukaryotic cells by bacterial secretion systems. Traffic 7, 929-939.

Cascales, E. \& Christie, P. J. (2003). The versatile bacterial type IV secretion systems. Nat Rev Microbiol 1, 137-149.

Cascales, E. \& Christie, P. J. (2004). Definition of a bacterial type IV secretion pathway for a DNA substrate. Science 304, 1170-1173.

Cheng, L. W. \& Schneewind, O. (1999). Yersinia enterocolitica type III secretion. On the role of SycE in targeting YopE into HeLa cells. J Biol Chem 274, 22102-22108.

Christie, P. J., Atmakuri, K., Krishnamoorthy, V., Jakubowski, S. \& Cascales, E. (2005). Biogenesis, architecture, and function of bacterial type IV secretion systems. Annu Rev Microbiol 59, 451-485.

Churin, Y., Al-Ghoul, L., Kepp, O., Meyer, T. F., Birchmeier, W. \& Naumann, M. (2003). Helicobacter pylori CagA protein targets the cMet receptor and enhances the motogenic response. J Cell Biol 161, 249-255.

Couturier, M. R., Tasca, E., Montecucco, C. \& Stein, M. (2006). Interaction with $\mathrm{CagF}$ is required for translocation of CagA into the host via the Helicobacter pylori type IV secretion system. Infect Immun 74, 273-281.

Deng, W., Chen, L., Peng, W. T., Liang, X., Sekiguchi, S., Gordon, M. P., Comai, L. \& Nester, E. W. (1999). VirE1 is a specific molecular chaperone for the exported single-stranded-DNA-binding protein VirE2 in Agrobacterium. Mol Microbiol 31, 1795-1807.

Drew, D., Sjostrand, D., Nilsson, J., Urbig, T., Chin, C. N., de Gier, J. W. \& von Heijne, G. (2002). Rapid topology mapping of Escherichia coli inner-membrane proteins by prediction and PhoA/GFP fusion analysis. Proc Natl Acad Sci U S A 99, 2690-2695.

El Etr, S. H., Mueller, A., Tompkins, L. S., Falkow, S. \& Merrell, D. S. (2004). Phosphorylation-independent effects of CagA during interaction between Helicobacter pylori and T84 polarized monolayers. J Infect Dis 190, 1516-1523.

Exner, M. M., Doig, P., Trust, T. J. \& Hancock, R. E. W. (1995). Isolation and characterization of a family of porin proteins from Helicobacter pylori. Infect Immun 63, 1567-1572.

Fischer, W. \& Haas, R. (2004). The RecA protein of Helicobacter pylori requires a posttranslational modification for full activity. $J$ Bacteriol 186, 777-784.

Fischer, W., Buhrdorf, R., Gerland, E. \& Haas, R. (2001a). Outer membrane targeting of passenger proteins by the vacuolating cytotoxin autotransporter of Helicobacter pylori. Infect Immun 69, 6769-6775.

Fischer, W., Püls, J., Buhrdorf, R., Gebert, B., Odenbreit, S. \& Haas, R. (2001b). Systematic mutagenesis of the Helicobacter pylori cag pathogenicity island: essential genes for CagA translocation in host cells and induction of interleukin-8. Mol Microbiol 42, 1337-1348 (Erratum in: Mol Microbiol 2003, 47, 1759)
Fischer, W., Haas, R. \& Odenbreit, S. (2002). Type IV secretion systems in pathogenic bacteria. Int J Med Microbiol 292, 159-168.

Franco, A. T., Israel, D. A., Washington, M. K., Krishna, U., Fox, J. G., Rogers, A. B., Neish, A. S., Collier-Hyams, L., Perez-Perez, G. I. \& other authors (2005). Activation of $\beta$-catenin by carcinogenic Helicobacter pylori. Proc Natl Acad Sci U S A 102, 10646-10651.

Ghosh, P. (2004). Process of protein transport by the type III secretion system. Microbiol Mol Biol Rev 68, 771-795.

Gilmour, M. W., Gunton, J. E., Lawley, T. D. \& Taylor, D. E. (2003). Interaction between the IncHI1 plasmid R27 coupling protein and type IV secretion system: TraG associates with the coiled-coil mating pair formation protein TrhB. Mol Microbiol 49, 105-116.

Gomis-Rüth, F. X., Sola, M., De La Cruz, F. \& Coll, M. (2004). Coupling factors in macromolecular type-IV secretion machineries. Curr Pharm Des 10, 1551-1565.

Guillemin, K., Salama, N. R., Tompkins, L. S. \& Falkow, S. (2002). Cag pathogenicity island-specific responses of gastric epithelial cells to Helicobacter pylori infection. Proc Natl Acad Sci U S A 99, 15136-15141.

Haas, R., Meyer, T. F. \& van Putten, J. P. M. (1993). Aflagellated mutants of Helicobacter pylori generated by genetic transformation of naturally competent strains using transposon shuttle mutagenesis. Mol Microbiol 8, 753-760.

Heuermann, D. \& Haas, R. (1998). A stable shuttle vector system for efficient genetic complementation of Helicobacter pylori strains by transformation and conjugation. Mol Gen Genet 257, 519-528.

Higashi, H., Tsutsumi, R., Muto, S., Sugiyama, T., Azuma, T., Asaka, M. \& Hatakeyama, M. (2002). SHP-2 tyrosine phosphatase as an intracellular target of Helicobacter pylori Cag protein. Science 295, 683-686.

Higashi, H., Nakaya, A., Tsutsumi, R., Yokoyama, K., Fujii, Y., Ishikawa, S., Higuchi, M., Takahashi, A., Kurashima, Y. \& other authors (2004). Helicobacter pylori CagA induces Ras-independent morphogenetic response through SHP-2 recruitment and activation. $J$ Biol Chem 279, 17205-17216.

Hofreuter, D., Karnholz, A. \& Haas, R. (2003). Topology and membrane interaction of Helicobacter pylori ComB proteins involved in natural transformation competence. Int J Med Microbiol 293, 153-165.

Hohlfeld, S., Pattis, I., Püls, J., Plano, G. V., Haas, R. \& Fischer, W. (2006). A C-terminal secretion signal is necessary, but not sufficient for type IV secretion of the Helicobacter pylori CagA protein. Mol Microbiol 59, 1624-1637.

Jakubowski, S. J., Cascales, E., Krishnamoorthy, V. \& Christie, P. J. (2005). Agrobacterium tumefaciens VirB9, an outer-membraneassociated component of a type IV secretion system, regulates substrate selection and T-pilus biogenesis. J Bacteriol 187, 3486-3495.

Lee, S. H. \& Galan, J. E. (2004). Salmonella type III secretionassociated chaperones confer secretion-pathway specificity. Mol Microbiol 51, 483-495.

Llosa, M., Zunzunegui, S. \& De La Cruz, F. (2003). Conjugative coupling proteins interact with cognate and heterologous VirB10-like proteins while exhibiting specificity for cognate relaxosomes. Proc Natl Acad Sci U S A 100, 10465-10470.

Mimuro, H., Suzuki, T., Tanaka, J., Asahi, M., Haas, R. \& Sasakawa, C. (2002). Grb2 is a key mediator of Helicobacter pylori CagA protein activities. Mol Cell 10, 745-755.

Moese, S., Selbach, M., Zimny-Arndt, U., Jungblut, P. R., Meyer, T. F. \& Backert, S. (2001). Identification of a tyrosine-phosphorylated $35 \mathrm{kDa}$ carboxy-terminal fragment $\left(\mathrm{p} 35^{\mathrm{CagA}}\right.$ ) of the Helicobacter pylori CagA protein in phagocytic cells: processing or breakage? Proteomics 1, 618-629. 
Nagai, H., Cambronne, E. D., Kagan, J. C., Amor, J. C., Kahn, R. A. \& Roy, C. R. (2005). A C-terminal translocation signal required for Dot/ Icm-dependent delivery of the Legionella RalF protein to host cells. Proc Natl Acad Sci U S A 102, 826-831.

Nikaido, H. (1994). Isolation of outer membranes. Methods Enzymol 235, 225-234.

Ninio, S., Zuckman-Cholon, D. M., Cambronne, E. D. \& Roy, C. R. (2005). The Legionella IcmS-IcmW protein complex is important for Dot/Icm-mediated protein translocation. Mol Microbiol 55, 912-926.

Odenbreit, S., Püls, J., Sedlmaier, B., Gerland, E., Fischer, W. \& Haas, R. (2000). Translocation of Helicobacter pylori CagA into gastric epithelial cells by type IV secretion. Science 287, 1497-1500.

Parsot, C., Hamiaux, C. \& Page, A. L. (2003). The various and varying roles of specific chaperones in type III secretion systems. Curr Opin Microbiol 6, 7-14.

Peek, R. M. J. \& Blaser, M. J. (2002). Helicobacter pylori and gastrointestinal tract adenocarcinomas. Nat Rev Cancer 2, 28-37.

Püls, J., Fischer, W. \& Haas, R. (2002). Activation of Helicobacter pylori CagA by tyrosine phosphorylation is essential for dephosphorylation of host cell proteins in gastric epithelial cells. Mol Microbiol 43, 961-969.

Rieder, G., Fischer, W. \& Haas, R. (2005a). Interaction of Helicobacter pylori with host cells: function of secreted and translocated molecules. Curr Opin Microbiol 8, 67-73.

Rieder, G., Merchant, J. L. \& Haas, R. (2005b). Helicobacter pylori cagtype IV secretion system facilitates corpus colonization to induce precancerous conditions in Mongolian gerbils. Gastroenterology 128, 1229-1242.

Rohde, M., Püls, J., Buhrdorf, R., Fischer, W. \& Haas, R. (2003). A novel sheathed surface organelle of the Helicobacter pylori cag type IV secretion system. Mol Microbiol 49, 219-234.

Sambrook, J., Fritsch, E. F. \& Maniatis, T. (1989). Molecular Cloning: a Laboratory Manual. Cold Spring Harbor, NY: Cold Spring Harbor Laboratory.

Schnaitman, C. A. (1971). Solubilization of the cytoplasmic membrane of Escherichia coli by Triton X-100. J Bacteriol 108, 545-552.

Schulein, R., Guye, P., Rhomberg, T. A., Schmid, M. C., Schröder, G., Vergunst, A. C., Carena, I. \& Dehio, C. (2005). A bipartite signal mediates the transfer of type IV secretion substrates of Bartonella henselae into human cells. Proc Natl Acad Sci U S A 102, 856-861.

Segal, E. D., Cha, J., Lo, J., Falkow, S. \& Tompkins, L. S. (1999), Altered states: involvement of phosphorylated CagA in the induction of host cellular growth changes by Helicobacter pylori. Proc Natl Acad Sci U S A 96, 14559-14564.

Selbach, M., Moese, S., Hurwitz, R., Hauck, C. R., Meyer, T. F. \& Backert, S. (2003). The Helicobacter pylori CagA protein induces cortactin dephosphorylation and actin rearrangement by $\mathrm{c}-\mathrm{Src}$ inactivation. EMBO J 22, 515-528.

Selbach, M., Moese, S., Backert, S., Jungblut, P. R. \& Meyer, T. F. (2004). The Helicobacter pylori CagA protein induces tyrosine dephosphorylation of ezrin. Proteomics 4, 2961-2968.

Seydel, A., Tasca, E., Berti, D., Rappuoli, R., Del Giudice, G. \& Montecucco, C. (2002). Characterization and immunogenicity of the
CagF protein of the cag pathogenicity island of Helicobacter pylori. Infect Immun 70, 6468-6470.

Suerbaum, S. \& Michetti, P. (2002). Helicobacter pylori infection. $N$ Engl J Med 347, 1175-1186.

Sundberg, C. D. \& Ream, W. (1999). The Agrobacterium tumefaciens chaperone-like protein, VirE1, interacts with VirE2 at domains required for single-stranded DNA binding and cooperative interaction. J Bacteriol 181, 6850-6855.

Sundberg, C., Meek, L., Carroll, K., Das, A. \& Ream, W. (1996). VirE1 protein mediates export of the single-stranded DNA-binding protein VirE2 from Agrobacterium tumefaciens into plant cells. J Bacteriol 178, $1207-1212$.

Suzuki, M., Mimuro, H., Suzuki, T., Park, M., Yamamoto, T. \& Sasakawa, C. (2005). Interaction of CagA with Crk plays an important role in Helicobacter pylori-induced loss of gastric epithelial cell adhesion. J Exp Med 202, 1235-1247.

Torruellas-Garcia, J., Ferracci, F., Jackson, M. W., Joseph, S., Pattis, I., Plano, L. R., Fischer, W. \& Plano, G. V. (2006). Measurement of effector protein injection by type III and type IV secretion systems using a 13-residue phosphorylatable GSK tag. Infect Immun 74, 5645-5657.

Umehara, S., Higashi, H., Ohnishi, N., Asaka, M. \& Hatakeyama, M. (2003). Effects of Helicobacter pylori CagA protein on the growth and survival of B lymphocytes, the origin of MALT lymphoma. Oncogene 22, 8337-8342.

Vergunst, A. C., van Lier, M. C., den Dulk-Ras, A., Grosse Stüve, T. A., Ouwehand, A. \& Hooykaas, P. J. (2005). Positive charge is an important feature of the C-terminal transport signal of the VirB/D4translocated proteins of Agrobacterium. Proc Natl Acad Sci U S A 102, 832-837.

Viala, J., Chaput, C., Boneca, I. G., Cardona, A., Girardin, S. E., Moran, A. P., Athman, R., Memet, S., Huerre, M. R. \& other authors (2004). Nod1 responds to peptidoglycan delivered by the Helicobacter pylori cag pathogenicity island. Nat Immunol 5, 1166-1174.

Vincent, C. D. \& Vogel, J. P. (2006). The Legionella pneumophila IcmS-LvgA protein complex is important for Dot/Icm-dependent intracellular growth. Mol Microbiol 61, 596-613.

Yokoyama, K., Higashi, H., Ishikawa, S., Fujii, Y., Kondo, S., Kato, H., Azuma, T., Wada, A., Hirayama, T. \& other authors (2005). Functional antagonism between Helicobacter pylori CagA and vacuolating toxin VacA in control of the NFAT signaling pathway in gastric epithelial cells. Proc Natl Acad Sci U S A 102, 9661-9666.

Zhao, Z., Sagulenko, E., Ding, Z. \& Christie, P. J. (2001). Activities of virE1 and the VirE1 secretion chaperone in export of the multifunctional VirE2 effector via an Agrobacterium type IV secretion pathway. J Bacteriol 183, 3855-3865.

Zhou, X. R. \& Christie, P. J. (1999). Mutagenesis of the Agrobacterium VirE2 single-stranded DNA-binding protein identifies regions required for self-association and interaction with VirE1 and a permissive site for hybrid protein construction. J Bacteriol 181, 4342-4352.

Edited by: L. S. Frost 